\title{
The Economics of Wealth According to Economic and Religious Principles
}

\author{
Alexandros M. Goulielmos ${ }^{1,2,3}$ \\ ${ }^{1}$ Maritime Division, Business College of Athens, Athens, Greece \\ ${ }^{2}$ Marine Economics, University of Piraeus, Piraeus, Greece \\ ${ }^{3}$ Department of Maritime Studies, University of Piraeus, Piraeus, Greece \\ Email: agoulielmos@bca.edu.gr, ag@unipi.gr, am.goulielmos@hotmail.com
}

How to cite this paper: Goulielmos, A.M. (2018) The Economics of Wealth According to Economic and Religious Principles. Modern Economy, 9, 1465-1489. https://doi.org/10.4236/me.2018.98093

Received: July 17, 2018

Accepted: August 28, 2018

Published: August 31, 2018

Copyright (C) 2018 by author and Scientific Research Publishing Inc. This work is licensed under the Creative Commons Attribution International License (CC BY 4.0).

http://creativecommons.org/licenses/by/4.0/

\begin{abstract}
We presented the issue of personal wealth drawing mainly from the economics of Keynes, and from New Testament, introducing the fact that a human being has two lifetimes. The second lasts an infinitum time, based on the assumption that soul is immortal. We showed also that "disutility of labor" and unhappiness introduced first by God; economists then tried to balance it with utility of consumption (in 1854) focusing on human body, and ignoring human soul, mind and their needs. We also presented as to how a World War can boost growth of GDP. When Ricardo raised the issue of how GDP is divided among factors of production, and that only labor creates value along with Marx, society divided, while religion wanted it united and peaceful. Protestantism made work as god. Concluding we said that an "uncontrolled personal wealth" is detrimental from both economic and religious point of view. Dealing with matters of Christian Orthodoxy for years, made us proficient. We believe, or rather audacious, to underline certain fundamental principles of it.
\end{abstract}

\section{Keywords}

Economics of Personal Wealth, New Testament, Keynes' Economics, Eternity of Human Soul, Disutility of Labor, Unhappiness of Present Life, What Is Truth, Managing the Plenty

\section{Introduction}

We believe that few know what their religion suggests on "basic economic issues", like e.g. on the question: "To create a personal wealth"? Many believe that religion has nothing to do with economics. However, three influential past 
economists: Lloyd, W.F. (1810-1858) (in 1833), Longfield, S.M. (in 1834), and ${ }^{1}$ Senior, N.W. (1790-1864), were Protestants [1]. Walras (1834-1910) believed himself to be a socialist and Marshall (1842-1924) had an early tendency towards it, as argued by Robinson, J. [2]. God has the first introduced disutility of labor.

Gossen, H. [3], who was anti-Catholic [1], first formulated the principles of "diminishing marginal utility" and of "marginal disutility of labor", rediscovered latter by Jevons (1835-1882) in 1878 and Walras (1834-1910), as in Figure 1.

Gossen [3], moreover, produced a negatively inclined demand curve from above. The doctrine of diminishing marginal utility applied to income, and pointed out to egalitarian principles [2], meaning to pursue equality among men (i.e. to apply "human justice").

Also the "labor theory of value" emanated from the Protestant outlook of the world...which meant to place labor at the center of theology. Protestants gave, we imagine, an alternative answer to Adam Smith (1723-1790), who asked "why some nations are rich and others are poor" (1776). At the same time, Protestants furnished, probably, Marx with a serious argument: that only labor creates value. "Hard work and only work" obviously is required by the Protestants for

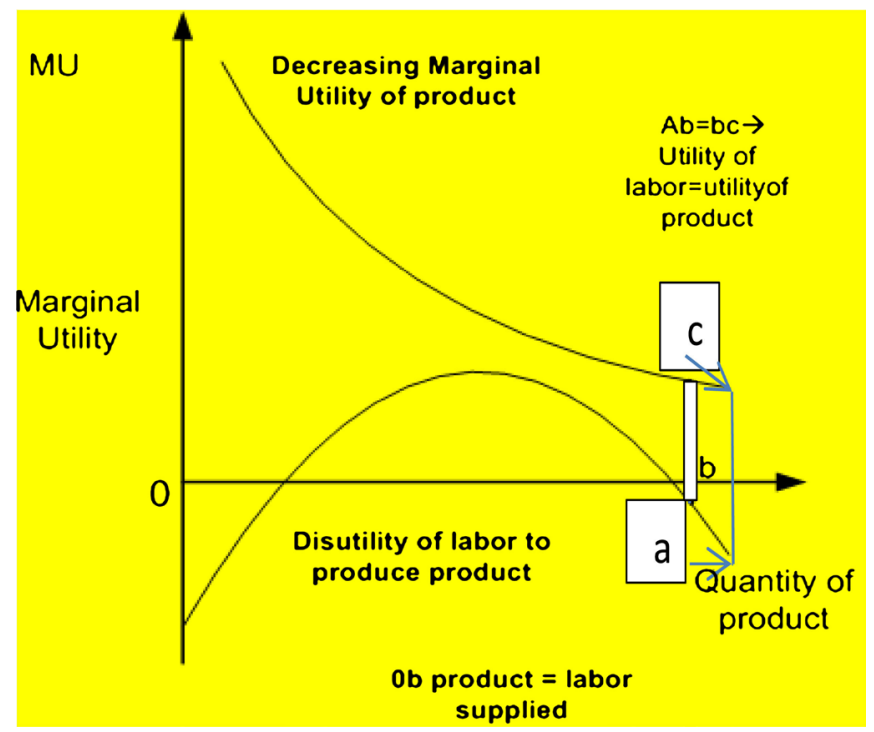

Source: Modified from that in Blaug [1].

Figure 1. Disutility of labor versus satisfaction released from the consumption of the product.

\footnotetext{
${ }^{1}$ Professor, Oxford University.

${ }^{2}$ This was Ricardo's theory (1772-1823) and Marx's (1818-1883) to explain the determination of price by the quantities of labor embodied in goods produced. Given that production is the common result of 3 factors of production, we believe, economists wanted to see the contribution of each. This divided those owning capital and land from those hiring their time and expertis. As "Income distribution" arose at that time by Ricardo (mentioned below). More important is that the above divided society into 2 classes: "laborers" and "capitalists". Peace and co-operation required by religion flew away! Economics also divided in two: 1) how economy works and 2) how economy should work. This $2^{\text {nd }}$ is based on "human justice" applying the rule of the "equality of measure", as mentioned. In contrast, Jesus Christ-JC mentioned a parable where a boss hired a series of unemployed during a work day and those hired in the afternoon were paid equally as those who started work in the morning ([4], pp. 89-91). Meaning of course that in the case of faith is not the duration, as we consider it in relation to labor, but the intensity or quality that matters.
} 
progress towards more wealth. Protestant Germany ${ }^{3}$ is a live example. Moreover, Christian Orthodoxy-CO asked: is a personal wealth in present life a wiser act than building it-up after death?

To acquire a personal income is surely a legitimate mean of preserving one's life etc. (by buying goods to eat, drink and dress, at least). CO allows no one to be idle [4]. St. Paul said: "who does not like to work ${ }^{4}$, he/she should also not eat" [4].

Among early Christians free food was provided to those who could not afford it at home, out of a spirit of common sympathy ${ }^{5}$ and solidarity [4]. Moreover, they sold their property and placed the entire money at the disposal of Apostles, so that to be given to those with no means according to their needs [4]. Solidarity and common property were the first principles among early Christians, meaning to think of, and provide to, poorer people by richer.

Now, to belong to a religion because it provides free meals, money or other material benefits, we believe is not according to "pure faith", or to personal dignity. Economists, moreover, insist that there is no such thing as a "free meal". Today, Greek Church provides free meals to those in need during the 2009-2018 economic depression.

Moreover, CO condemns anyone becoming rich by pretending to have extraordinary abilities to work out miracles by: juggling, magic, or as a medium, or as an astrologer or using any other of devil's devices. Faith is not permitted to be used for personal profiteering.

How then Jesus Christ-JC provided a massive free meal (bread and fishes) two times? These were special circumstances and he did that out of sympathy for his audience, being without food for 3 days, in the desert, and in order to listen to him! The number of persons fed was 5000 males. Naturally, they subsequently wanted to proclaim him King [4]. JC has made, in his $1^{\text {st }}$ miracle, also the best wine out of water [4] in a close circle, during a marriage ceremony, to make his 4 first disciples believing in him as his mother Maria believed.

To provide free meals permanently is against God's decision, who told Adam upon his fall: "from now on you have to earn your living, cultivating soil in the hard way" . JC also said "seek the Kingdom of Heavens first" and "all that you

\footnotetext{
${ }^{3}$ In a graph from the internet source: "religion-economy", Germany had $\$ 38,000$ annual per capita income and it was in the middle of religiosity (50\%). Romania is highest near $98 \%$, followed by Poland (80\%) and Italy (75\%); Belgium and USA 60\%; last is China after Japan (10\%). Switzerland is on income top with $\$ 48,000$ (50\%). Most (18) poor countries with income pc $<\$ 10,000$ p.a. have a higher degree of religiosity $>60 \%$ with the exception of Vietnam and China. It seems that poorer people have higher degrees of religiosity (being religious). FYROM is wrongly mentioned as Macedonia.

${ }^{4}$ St. Paul covered all his personal expenses by his work [4], though he was entitled to.

${ }^{5}$ St. Paul stressed that "agapes" are not the place for someone richer to bring in his/her meal to eat it there, but an opportunity to share it with poorer.

${ }^{6}$ God said to Adam: "By sweating your face you are going to eat your bread" ([6], Chap. A); "You will cultivate soil". Labor thus established by God, together with its disutility. Adam had to deal with Agriculture and Cattle-raising, as his 2 sons also did: Abel (cattle-raising) and Cain (agriculture). God added: "in sorrows you will live". So this life, as prescribed by God, will not provide happiness, as economists argue (utility theory). By the way, Adam did not ask for forgiveness from God, though he felt his guilty by hiding himself and by seeing that he was naked. God, however, gave him enough time to think, as he appeared in the evening of the fall day [6]. Moreover, Adam held. God was responsible for his fall by saying: "the woman you gave me", she "pushed" me to disobey you (in our words) [6]!
} 
need they will be added to you" [4]. Laziness is inconceivable in either spiritual or body endeavors.

The concept of "disutility of labor", adopted by classical economists to build up their theory of employment, was first established by God after Adam's fall, as mentioned! Keynes [5] argued that "the utility of wage, (when a given volume of labor is employed), is equal to the marginal disutility of employment" or $\mathrm{MU}_{\mathrm{W}}=$ $\mathrm{MDU}_{\mathrm{L}}[1]$.

Wealth is a stock and income is a flow. Income, however, has no great religious interest. Income is derived from the "ability" of a man, acquired by education etc., to hire his/her time to an employer, against a salary, and an eventual pension. This is a universal phenomenon. Wealth, however, has a great variety, defined below, and is an act of accumulation.

Keynes [5] mentioned the post-war experiences of GB and USA, where a great accumulation of wealth led to the fall of MEC (marginal efficiency of capital) to be $>$ than the fall of the rate of interest. This prevented a reasonable level of employment, and an attainable standard of living (italics and bolds added). So, wealth is a bad phenomenon for this great economist.

Earning no-income due to lack of demand, is no doubt a sad human situation, and any religion (and government) has to care about by providing free food, clothing, cash, medical care, shelter, etc. We have witnessed persons who lost their job and were unable to find a new one during a crisis $\left({ }^{*}\right)$ due to their somehow advanced age; $\left({ }^{*}\right)$ during end 2008 meltdown.

Religion deals par excellence with rich people. Surely, any wealth illegally obtained on the basis of any spiritual, moral or human laws is out of question (i.e. drugs, prostitution, selling protection, smuggling, arms' trade, trading human organs, forced immigration etc.). This will be not discussed. A serious work has been published on these issues. The exploitation of one from the other is deemed impermissible, as love there is absent [4]. CO's motto is: "Do to others, whatever you like others to do to you" [4]. People living in Judaea had the wrong opinion about wealth as they believed that it is given to them by God to reward them for their justice [4]! This is also believed by Protestants.

A number of Greek shipowners, and other Greek entrepreneurs, established plethora of beneficial funds and benevolent establishments out of their personal wealth after death (Niarchos, Onassis, and many others), Keynes [5] was especially critical for such action.

Economists were confused by treating "personal wealth" the same way they treated "National wealth". This was a serious mistake as we know now, after Keynes, that the part of income, which is not spent on consumption, it must spent on investment (in fact we know how and why) to proceed to a growth of income and employment.

In a summary, we see that the "disutility of labor" and "unhappiness" during present life introduced first by our father (God), soon after our ancestors, Adam and Eve, fell. As a result Gossen discovered in 1854 the "utility of consuming" a 
good and the "disutility to work". These two concepts provided one of the 3 revolutions in economics: the "Marginal" Revolution" in 1870s. There was of course the Epicurean philosophy (300 BC) arguing that: "let us eat and drink for tomorrow we die". Moreover, Bentham (1748-1832) believed that the end of life is happiness (=pleasure).

As a result economists understood that there is something to maximize there in consuming goods, and enjoy life, but this needed mathematics. In addition the displeasure from work could now be compensated by the pleasure of consumption. The three substances of humans, brain, soul and body restricted to one: the body. The remarkable issue is that both Religion and Keynesian economics agree that wealth (not spent) is detrimental for either life after death or for the growth of economies. This is our main finding.

This paper does not pretend to have exhausted all religions in what they believe. For Catholicism and Protestantism we have given their basic differences one to other and with Christian Orthodoxy. The emphasis is on Christian Orthodoxy no doubt.

\section{Aim and Structure of Paper}

Our purpose is to deal with wealth within an economic and religious framework. The main stream economics deals with the "economics of scarcity". This paper triggered also by the psychological fact noted by Keynes [5], in connection to his critique on mercantilism, that a man prefers to build-up his personal wealth, than to promote his/her country's GDP. Moreover, reference is made here to 3 religions only due to lack of space: Protestantism ${ }^{8}$, Catholicism and Christian Orthodoxy-CO.

The paper is organized as follows: next is a Literature Review followed by (a) Economic Theories and (b) Religious theories, based on CO. Then it follows the Economics of Wealth I. Next two parts follow: the further basic concepts of Christian Orthodoxy I and II. Next are human Economics and the Economics of Wealth II. Finally, we conclude.

\section{Literature Review}

Walras in 1873 had to prove that "free competition" provided the maximum utility; so, inequality of income is justified [2] on the grounds that only rich save and accumulate capital (bolds added). With the utility theory came mathematics, which promised a new dawn for economics, as a truly scientific subject, something welcome by Jevons. Moreover, Edgeworth ${ }^{9}$ (1845-1926), a utilitarian, showed (1881) that happiness can be measured as a 2-dimensional quantity vis-à-vis intensity and time (bolds added)! In addition, Ricardo (1772-1823), argued that wealth means accumulation.

${ }^{7}$ Thirty one terms in economics use the term "marginal".

${ }^{8}$ A type of Christianity stemmed from "reformation", which took place in $16^{\text {th }}$ century. It adhered to Martin Luther. It is applied to most Western Churches other than the "Roman Catholic Church".

${ }^{9} \mathrm{He}$ replaced Senior in Oxford University. 
Weber $^{10}[7]$ examined the relationship between areas ${ }^{11}$ of rapid economic development and religion. He found that in countries with Protestants ${ }^{12}$, as well Roman-Catholics, the entrepreneurs, the capitalists, the persons with technical education and the specialized laborers, were mainly Protestants!

Keynes [5] argued that the desire of a person to increase his personal wealth, by abstaining from consumption, is usually stronger than the inducement of an entrepreneur to increase national wealth (bolds added). This, in our opinion, is a serious economic problem, which leads an economy to induce people holding wealth to "transform" it into savings at least, or preferably, into investment by establishing higher rates of interest exclusive for cash proved to come from wealth or hoarding.

In Greece hoarding is estimated to be equal to $€ 40$ billion (!), especially after capital controls. Hoarding is diminished in Greece by taxation and by burglars. It is increased due to low rates of interest and the uncertainty for the integrity of bank accounts (fear of a hair-cut), etc.

Robinson [2] argued that the basic human need for morality, on which conscience works, leads to the necessity for a "philosophy of economics", which she wrote. The relation between "science" and "ideology" since 1760s can be traced from Adam Smith (1776) to Marx (1867-1894) and to Keynes (1936-1946). Has this led to the dichotomy of economists into Capitalists and Marxists? Ideology split people into 2, while religion wishes it to be one. We believe that Keynes admitted that Marx was somehow right, but he thought that economists can fix capitalist economy as "economic engineers"! Keynes accused the capitalist system as a system creating recessions, depressions and crises [8].

Robinson [2] argued that: ideology in economic life plays large part, and economics was partly a vehicle for the ruling ideology, and partly a method of scientific investigation (bolds added). Moreover, the hallmark of a metaphysical proposition is that it cannot be tested (ibid, p. 8); the metaphysical statements

\footnotetext{
${ }^{10}$ Weber followed French reformer Jean Calvin (1509-1564), rather than Luther, who argued that "Scripture" is the sole rule of faith, and justification is by faith alone. Calvinists came to value profit and material success as signs of God's favor. Calvin departed from Lutheranism by arguing that "the divine will" is absolutely sovereign, there is a predestination (of those to be saved and the rest), and an impossibility of grace, once given, to be lost. Moreover, the authority of the Scripture is made known to a believer by the "internal witness of Holy Spirit". Contra to this, CO argues that grace does not stay permanently to a baptized Christian originally given to, but it goes away, and returns, when it finds a holy ground, (i.e. love for JC and for other people and especially keeping JC's commands) ([4], p. 3; p. 1024; p. 1034). The possibility of Salvation is for all. Also, faith is not alone able to save a believer, if not followed by actions ([4], p. 30; 983). Faith surely is the key of the door for a believer to enter the "Kingdom of Heavens", we believe. Also, a believer has to participate in the relevant sacraments, especially: baptism, confession (repentance), and Eucharist (Holy Communion). One may be misled, as Calvin, by the insistence showed by JC in NT [4] to seek first faith, as a prerequisite for his miracles. But a careful study of the NT [4] shows that faith with no actions is considered dead ([4], p. 983). Surely, JC had to be lenient in his early teaching delivered for the first time. He had to be gradual. True that with faith (and humility), we believe, one does the $1^{\text {st }}$ necessary step, and without these 2 , humans do never the 2 nd step, i.e. to proceed to actions.

11 "Lutheranism" practiced mainly in Germany, and established also in Denmark, Norway and Sweden, and represented widely in USA.

${ }^{12}$ This name comes from the "protestation" of the reforming members of the "Diet of Spires" (1529), against the decisions of Catholic majority; it is adhered to Martin Luther (1483-1546).
} 
have, however, content (p. 9); they express a point of view, and form feelings, which guide conduct; these feelings are not science, but they are necessary to science (italics added); a moral sense is a propensity to develop a conscience ( $\mathrm{p}$. 13).

She further argued (p. 14) that in most societies, morality came from religion, which is a useful way of strengthening the desire of the individual to do whatever he/she thinks right, and of imposing a particular view of what is right (italics added). Apropos Robinson quoted: "If there is no God, nothing is forbidden" (p. 14) (bolds added). Robinson (p. 15) quotes also that some argued that organized religion is necessary to good conduct and social harmony (italics added). She also argued that the moral feelings do not derive from either theology or reason.

Religion she said had not much to do with the economic ideology (p. 19), and she quotes: "how hardly shall they that have riches enter the kingdom of God" (bolds added). "Economics is not only a branch of theology, but all along it has been striving to escape from sentiment and to win for itself the status of a science." (p. 25) (italics added). So, Robinson, J. was irreligious, we reckon.

Robinson [9] wrote that economics is the scientific study of wealth, and yet economists cannot measure it. One is then surprised to find out that she devoted, however, less than 1.5 pages to it.

Blaug [1] argued that there was a delayed acceptance of the "utility theory"13 in England (and Germany) on the grounds that the subjective "theory of value ${ }^{14}$ " was a product of the Catholic culture. True is that Catholic philosophy exalts moderate pleasure, seeking instead of work, and of money making. Given that Catholicism ${ }^{15}$ dominated Continent, then the prevalence of utility theory in $18^{\text {th }}$ century among French and Italian economists was to be expected. This is another indication that religion influences economics. Today, Italy is a country where a bank is named after the "Holy Spirit ${ }^{16 "}$.

Varian [10] argued that in Victorian days (1819-1901) "philosophers" and "economists" talked of "utility" as an indicator of a person's overall well-being, or a numeric measure of a person's happiness! (exclamation mark and bolds

\footnotetext{
${ }^{13} \mathrm{~A}$ good must have utility, or usefulness, in order to be produced or exchanged.

${ }^{14}$ Every good has an intrinsic value. Value in terms of money determines price. Value is distinguished in "value in exchange" and "in use". Value in use means good's capacity to satisfy human wants. Value in exchange is the worth of a good in terms of its capacity to be exchanged for another one. This last depends on costs of production (wages, profits and rents).

${ }^{15}$ The "Roman Catholic Church" believes that: 1) it is the only "catholic"; 2) it has the authority and continuity of the (Historic) Church; 3) the organized ministry is important; 4) Papacy is the fount of authority, and 5) sacraments are indispensable. CO claims contra that the Holy Spirit derives exclusively from Father. Difference also exists in the Holy Communion ("transubstantiation" holds for Catholics); the Holy Communion is the "body and blood of JC" for CO. Catholic saints are not recognized after "Church" divided into 2 (1054; the "Great Schism"). JC is the supreme authority, equal in value to father, and the Holy Spirit acts mainly only through Saints. Moreover, the supremacy of the Papacy rejected also by the following 3 reforming movements: Evangelical (Lutherans), Reformed or Presbyterians (Calvinists) and Anglican Communions (1534). Source: The Reader's digest great encyclopedic dictionary, 1964, Oxford University Press, $3^{\text {rd }}$ volume.

${ }^{16} \mathrm{He}$ is the $3^{\text {rd }}$ person of the holy trinity.
} 
added). Consumers had to maximize utility, or happiness, but these 2 unfortunately could not be measured.

Iyer [11] in her working paper argued that the economics of religion is a relatively new field of research in economics and she presented an 88 pages survey. She argued that for an economist is difficult to comment on personal religious faith appropriately. We did.

Summarizing: Economists abandoned the relation between utility and happiness, and adopted the theory that consumers are in a position to prefer a bundle of goods A from B, on the basis of their "ordinal" utility. This indeed was something more human.

Newer research must be carried-out to see if a "particular religion" is related closely to persons in a society who excel ${ }^{17}$. If this is true then this indicates another way to achieve growth perhaps in the long run. Robinson argued that ideology was responsible for the dichotomy of economics, and the dichotomy of human race we add. This is against religion wanting people to be peaceful and united ([4], p. 897).

Keynes [5] quoted a letter of Ricardo to Malthus (in 1820) saying that: "the political economy you think as an enquiry into the nature and causes of wealth, I think it should be an enquiry into the laws determining the division of the produce of industry amongst the classes, who concur in its formation, the true object of science". Blaug finally described the influence of religion on basic economic theories like the "theory of value and utility".

\section{Methodology}

We selected from NT all relevant quotations about the subject of our research and put them down. In matters of faith, what is relevant is what the founder of $\mathrm{CO}$ said (JC). The main points of two religions, i.e. Protestantism due to Calvin, and Catholicism, which followed the great schism in 1054, were mentioned. Our personal experience and study of $\mathrm{CO}$, over 30 years, enabled us to write about $\mathrm{CO}$ in more detail, but errors and omissions have to be forgiven.

\section{Economic Theories}

Early writers argued that the metaphor of "the invisible hand" means "the hand of God" ruling the "social world", as he is ruling the "natural world". Provided free will of any human is not violated, we add. Adam Smith, who wrote first about the invisible hand, is considered a deist (i.e. having faith derived from reason), or atheist [1].

The $1^{\text {st }}$ subject of economic discussion was the "proper" level, and the "moral" justification of interest. Moreover, there was an economic doctrine that the rate of interest is not self-adjusting at a level best suited to social advantage, but it constantly tended to rise, so that a "wise" Government had to be concerned to ${ }^{17}$ Achilles's father Peleus told to his son going to "Trojan War": "Go and try to excel and distinguish yourself". Economists introduced a related concept that of "human capital” in 1964 (Becker, [12]). See also Teixeira [13]. 
curb it by statute, custom, or even by invoking the sanctions of Moral Law [5] (bolds added).

For Classical economists, the existence of interest was a sign of productivity, and is determined by the demand for funds to be invested, and thrift (=supply of savings $\left.{ }^{18}\right)$. For Keynes $[5]^{19}$ interest was also an important tool, but is determined differently, i.e. by the supply and demand for money. But it was necessary to be fixed at a lower level than the MEC to induce investment, given: a favorable level of confidence, existence of animal spirits and the absence of a liquidity trap for us.

Provisions against usury ${ }^{20}$ were frequently recorded in the ancient economic practices. The ancient and medieval world believed that the excessive demand for money (=liquidity-preference) was the prime evil destructing the inducement to invest-and a prime impediment to growth of wealth.

Keynes [5] mentioned that he was brought-up to believe that the attitude of the "Medieval Church" (UK) towards interest, which was inherently mistaken. Keynes further [5] argued that classical theory confused the two fundamental concepts, i.e. the "rate of interest" and the "MEC". The first had to be down and the second had to be up. In addition, Adam Smith was extremely moderate in his attitude towards usury laws ${ }^{21}$.

Capitalistic system seems to need wars and destructions to achieve thereafter exceptional growth rates! Keynes argued that civilization cannot be found, except where there were earthquakes to proceed to a reconstruction boom. He also wrote that Pyramid-building, even wars, may serve to increase wealth (bolds added). Wars [5] were just the only forms of large-scale loan expenditure ${ }^{22}$.

Figure 2 and Figure 3 indicate high growth rates after wars (!), like after 1945, par excellence, and after 1918, following the "Great War".

In CO JC is reported [4] to condemn the person who received a certain amount of working capital from his boss, but he failed to increase it by further work. Alternatively he could deposit it to a Bank to gain interest. JC apparently was against hoarding and he did not condemn "interest". Surely, the above parable

\footnotetext{
${ }^{18}$ Classics believed that what is saved is automatically invested via the rate of interest. For Keynes different people save and invest.

${ }^{19}$ Worth noting is what J. Robinson wrote in her book "Economic Heresies" (in 1971) (p. 80) about chapter 17 of Keynes on "properties of interest and money", that she found it difficult to follow; Keynes said that this was so also for him!

${ }^{20}$ Usury is a case where excessive interest on loans is charged vis-à-vis the market rate on loans with similar risk. Usury nowadays is applied by banks when they charge $\sim 21 \%$ p.a. for credit cards allowed by governments. This is "legal usury" where the rate of interest on deposits is $<1 \%$.

${ }^{21}$ Usury laws restricted the level of interest charged or paid for loans. One studying economics can observe that "excessive profits" (from oligopoly or monopoly) are considered beneficial to society, as holders of them par excellence invest. Perhaps this psychological phenomenon is related to the fact that the amount of wealth diminishes the importance of wealth held. JC observed that a poor widow put in the vault of the Solomon Temple 2 cents: all her fortune ([4], p. 203). She put more than anybody else! So, the more one has, the easier he/she spends, (except in cases of miserliness), as the importance of money is related negatively with the quantity of money held. This also happens with the stock of goods: the more one has, the less appreciates them. Also, the easier one obtains something, the less appreciates it.

${ }^{22}$ Public investment financed by borrowing from individuals.
} 


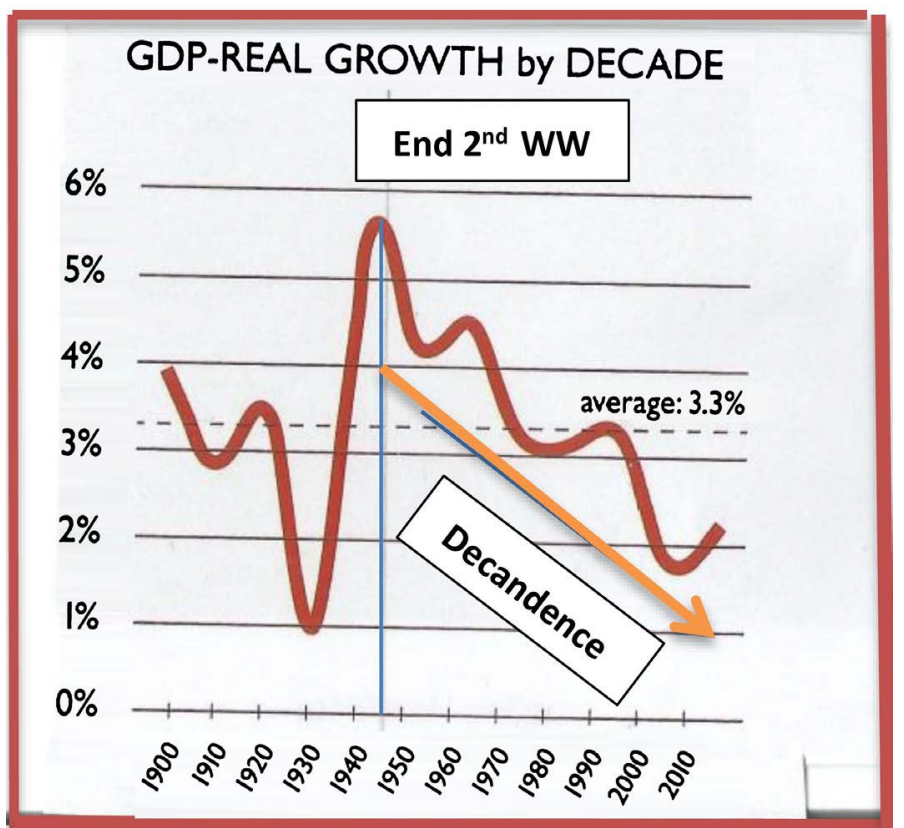

Figure 2. Global GDP growth 1900-2010. Source: Data from IMF.

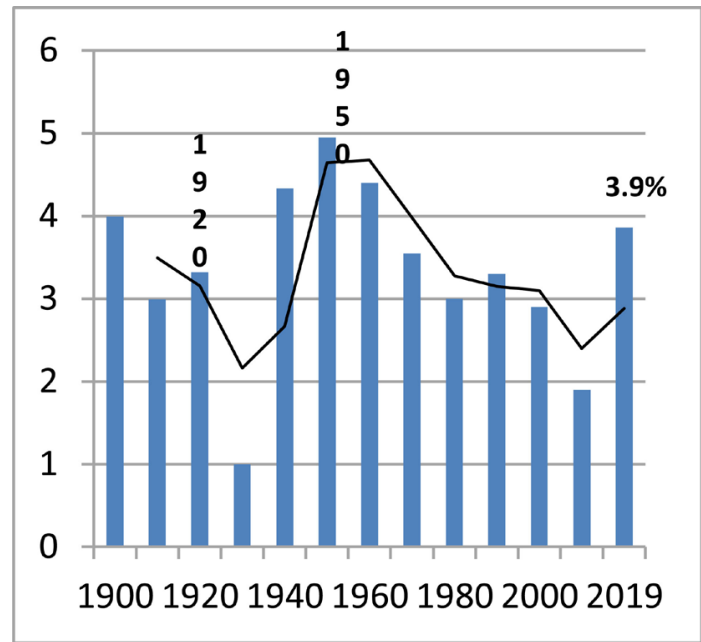

Figure 3. Global GDP growth to 2019. Construction by author.

refers not so much to "monetary capital", but to "spiritual one", or to "human good natural properties", which everybody endowed with by birth, and should be used to be rather increased. Also, JC was clearly against idleness [4]. Many times JC mentioned that he works all the time and his father does too [4], and he worked even during Sabbath ${ }^{23}$, which for people of Judaea was for rest and divine worship. JC, therefore, established work especially towards "spiritual endeavors". But this principle is general.

JC was also strongly against exploitation of man by man, in general, and especially in the "trade" taking place in "Solomon Temple" by those exchanging for-

${ }^{23} \mathrm{JC}$ showed that he was above OT, as he was the lawgiver of OT [6] and NT [4]. He "completed" OT, and made its requirements higher, as his grace provided is higher, after his sacrifice and the restoration of love between his father and humans. 
eign currencies and selling worship goods ${ }^{24}$. He used a hand-made whip from ropes and threw sellers out and overturned their tables. Certainly JC's motive was not only to clear-out his father's house from thieves, as it was a holy place requiring respect, but also to condemn worshipers' exploitation lacking love [4]. This was also an action of zeal for the glory of his father's house as this was pre-written in the Psalms.

Moreover, he showed several times that his justice can be severe, as the case may be, to combat, or prevent, further human malice [4]. A related action was also that against fig-tree, which cursed for providing no fruit at that time; he wanted to show that his love goes along with his justice and who does not provide fruits to those required them. He/she may face death [6].

In addition, $\mathrm{CO}$ is based on love: love for children from their parents; love for one's wife, where two bodies become one by marriage and the sexes are only two and wife is only one; love for enemies; and love for God and his son. Cases of love separate $\mathrm{CO}$ from religions provoking hate and causing death to un-believers. The ancient Greeks had also a God for war: the Ares! But Greeks ${ }^{25}$, cleverly, made Gods after them, while for CO the first couple was made by God after Holy Trinity in two only counts: "mildness" and "full power over all animals".

Wars, however, are required, serving God's pedagogical plans each time (JC) [4]. Surely, economists should not be in favor of wars because they allow thereafter for an exceptional growth rate $^{26}$ !

\section{The Economics of Wealth I}

Given that a person is able to hold assets $\left(\right.$ net $\left.^{27}\right)$ then the monetary value of them in the market is his/her wealth. The assets, exclusively those marketed, are listed ${ }^{28}$ below. Gurley and Shaw [14] distinguished money in "inside" and "outside", where changes in the real amount of them, held by private sector, had differing wealth effects. The inside money, like bank balances, is a personal asset for its holder (but liability for somebody else); the golden coinage is "outside" money. The real value of "inside" money does not help the building-up of wealth of an economy. Their monograph was an attempt to construct a unified theory of Money and Finance as suggested by Hicks in 1935 [15].

As shown (Figure 4), there are 3 curves of demand and supply of a bundle of

\footnotetext{
${ }^{24}$ Selling sheep, cows and pigeons.

${ }^{25}$ In $6^{\text {th }}$ century B.C. Parmenides and Zenon founded the Eleatic school of philosophy, which combated the anthropomorphic religion of the ancient poets and maintained that there was a single eternal god not resembling mortals in appearance or thought.

${ }^{26}$ Greek ship-owners obtained high profits during the France-England war in round $1815 \mathrm{~s}$ and the sea blockade of France.

${ }^{27}$ "Net" means that we subtract all debts owed by wealth-holder.

${ }^{28}$ Indicatively wealth consists of: cash, foreign exchange, precious metals, jewels, stocks of goods-spare parts-building materials-raw materials, shares, bonds, lands, buildings, yachts, aircrafts, cars, ships, rents, life insurance policies, intellectual properties and rights on them (i.e. patents, copyrights, on books, on songs etc.), collections, claims for loans, works of art and any other valuable object exchangeable for cash.
} 


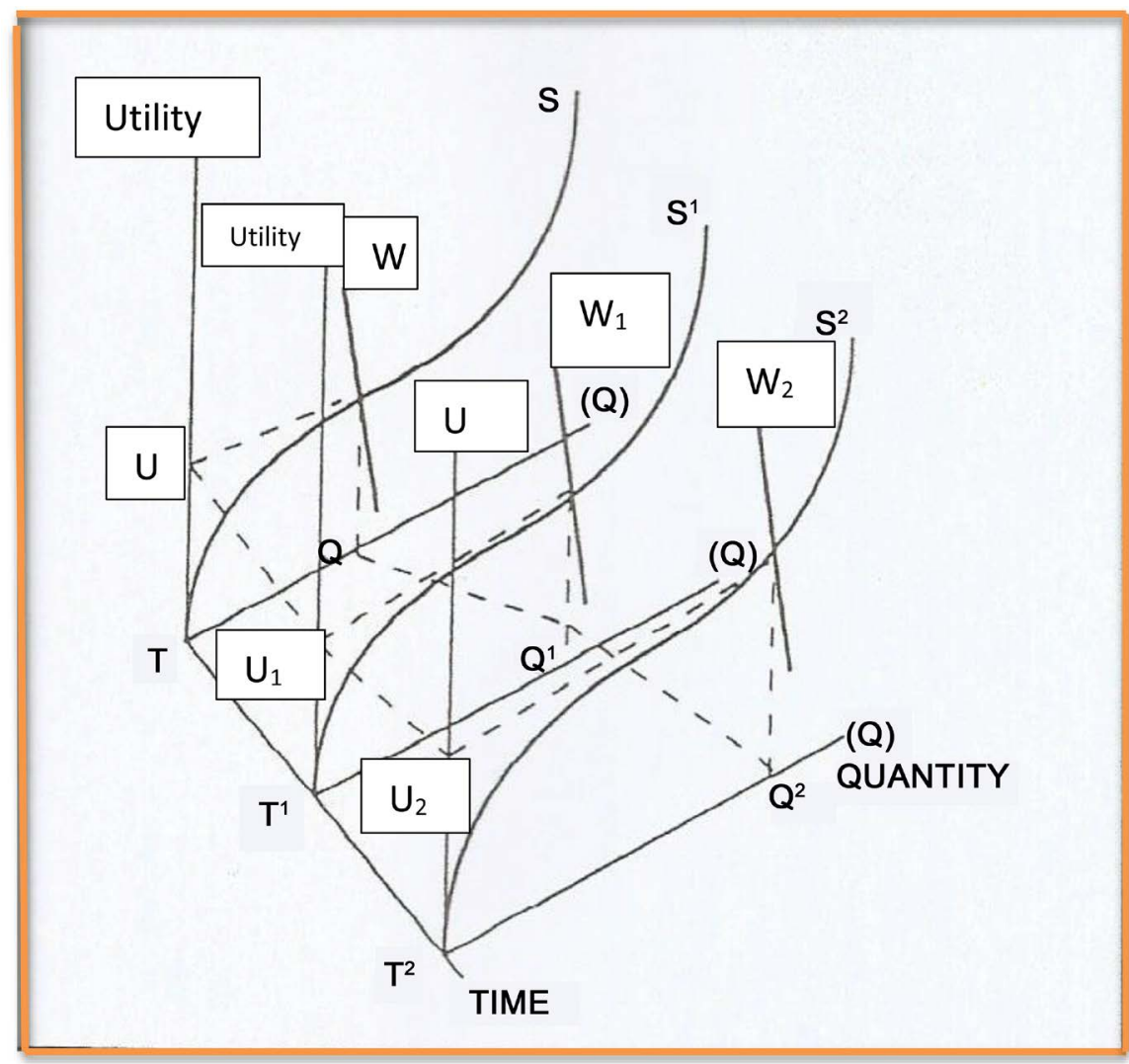

Source: Author.

Figure 4. Utility derived by wealth, time and demand/supply interaction.

goods A, for consumption during present life. T now is assumed to be equal, and not less, to one's certain age, say 30 years $^{29}$ of age, so that to be able to build-up a personal wealth, saving part of his/her income (I).

There are two further time milestones: $T_{1}$ and $T_{2}$. We assume $T_{1}$ to be at one's middle life, say at 45 years of age, and $\mathrm{T}_{2}$ to be at wealth-holder's death, say round 90 years. If $\mathrm{T}_{1} \mathrm{~T}_{2}=0$, as happened to "rich man" mentioned in the NT [4], the amount of his wealth, (less inheritance tax), is for his heirs!

The composition of the bundle of goods A is not fixed and it may be different over time, taking into account a change in tastes as Figure 4 depicts a "lifetime" period. As shown, as quantity consumed increases, utility increases, and time and wealth also increase ${ }^{30}$. The amount of utility depends: on the quantity of goods demanded, on the quantity of goods supplied, on the amount of wealth spent, given prices which are not shown, but they are expected to rise due to inflation and on time. Many say death is certain, why not then introduce it in our analysis?

Further, we can bring-in also wealth in a number of indifference curves. Wealth producing cash leads to a higher satisfaction as allows a movement to higher indifference curves towards the right side (Figure 5). So, religion is right

\footnotetext{
${ }^{29}$ Exempting cases of wealth obtained from inheritance.

${ }^{30}$ This describes a normal situation.
} 


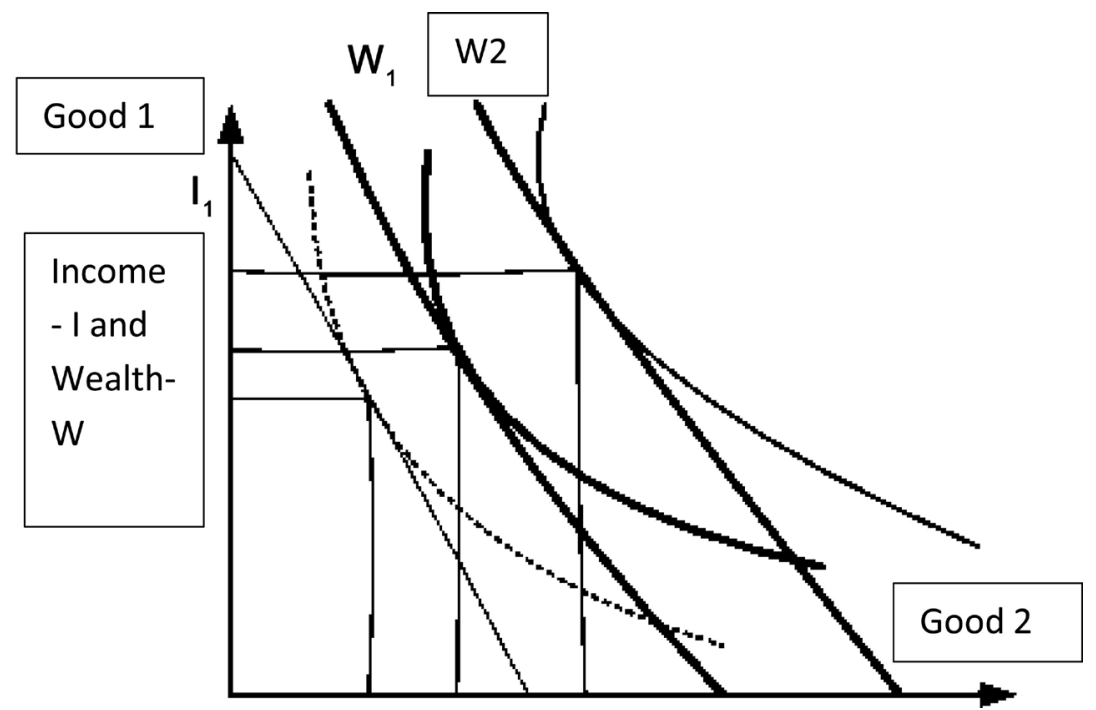

Source: Author.

Figure 5. Indifference curves versus income and wealth.

by saying that wealth can be used to enjoy life.

\section{Further Basic Concepts of CO-Part I}

Conscience, we believe, is not an exclusive result of learning like the language we speak, or it does not depend only on the kind of society we grow-up, but it is a criterion of "right and wrong" inherent in Man's nature, placed there by God, causing the well-known "remorse". Life, we believe, will be radically different, if conscience is completely removed or substantially minimized. Surely, the way Christians live gives an example to non-Christians; also the way one's parents or priests behave gives an example especially to children. Teaching nowadays of what is right and what is wrong is exclusively done by one's example than by talking.

To correct the society, we believe, one has first to correct the information flow. People copy what the majority of people does; what friends tell and do; what magazines write; what TV presents; what press writes; what books write; what films show etc., assuming that all these indicate the right way to behave and live. But all these are written by humans with passions, own purposes and complete ignorance about reality! One should study NT if he/she wants to know the "hyper-philosophy", which solves all human problems according to Saints.

Some say that metaphysical statements cannot be tested, and for this reason they reject faith, and God, pretending to be atheists ${ }^{31}$, but all have their god: real or false!

Life after death or "Lad" is the core chapter. It is worth noting that St. Paul devoted 6 pages to this [4]. If there is no "lad", it means that the whole dramatic effort of JC was a fiasco. Moreover, JC apparently failed in his mission [4]. JC's

${ }^{31}$ Many "gods" are created by men; "a human is slave to whatever passion he could not win" ([4] p. 1017); any passion is "god" for those who exercise, love, obey and worship it. 
mission was exactly to provide convincing evidence that he can win the two D's: devil and death for the time being, and to complete his victory finally with the aid of his father in his "second coming back" [4].

JC opened an account with D since the time of Adam and Eve, as D succeeded in "killing" them both [4], out of personal envy. They confined to the "dead" after their murder, and transferred by JC after his resurrection; they are now waiting to pass "burning river" with the rest of humans.

D failed to "kill" JC, though he had a time advantage, given that JC was starving, after 40 days and nights of fasting from food and water! Moreover, $\mathrm{D}$ had his early doubts as to whether JC was an “ordinary man”, or “son of God”. D's effort thus was also to clear this out, despite the fact that D heard God to name JC his son, during JC's baptism [4]. But D, however, thought slyly that JC cannot be son of God, and at the same time starve! As a result, the 2 of D's questions started stereotypically: "if you are son of God".

First D asked ${ }^{32}$ JC to make a miracle to prove who he was, by producing "bread" out of a "stone". This would, if carried out, prove that JC's belly was dominant as in Adam's case, and prove also the vainglory of JC, as God could do that not JC (being a human). JC replied that a man cannot "live" by just eating bread, but with every word that comes out from God's mouth (as written in "Deuteronomy").

$\mathrm{D}$ then brought JC on a tall mountain and showed him all Kingdoms and their riches. D promised to give all these to JC, as D claimed falsely to be his, if JC recognized him as lord and worshiped him as god. Riches, human glory and magnificence were here the baits. JC sent D away saying that only God has to be exclusively worshiped.

Then D brought JC through air on the edge of the roof of Solomon's Temple in Jerusalem, and said: "Drop yourself down to prove the love and the protection, which your father will offer to you, as this is written twice in Psalms". JC then replied: "one should not expose himself in danger to test God by finding-out from facts, if God will protect him" [4].

JC argued that God is not God of the dead, but of the alive [4]. This is the most serious claim. If God was a God of the dead, his kingdom would have no meaning, as dead "feel, believe, worship and do" nothing. Ancient Greeks had a God of the dead: the Hades; but they were clever enough to consider dead bodies alive (Homer's odyssey).

No "lad" means that God was unable to give life. But this gives also evidence that also Adam and Eve could not be alive. How then D is a living creature? JC used a piece of information about "lad" by saying that "Abraham, Isaac and Jacob", were alive, though "died" centuries ago [4]. This indeed puzzled the religious officials listened, as though JC was round 33 years of age, he said he saw the above 3 Patriarchs! Abraham is also reported alive holding "poor Lazarus" in his arms [4].

${ }^{32} \mathrm{D}$ out of his thousand years of experience in "killing" men and women used the same 3 weak points of all humans. All humans fall-in all 3 or 2 or 1 of the above traps. 
Moreover, JC told to the co-crucified thief, who asked for JC's mercy upon JC's arrival at his kingdom in heavens: "I assure you that today you will be with me in Paradise (!)" [4]. This miracle has an important and distinct meaning, we believe, as JC, though he resurrected at least 3 already dead, (notably: the "Lazarus of Bethany", dead already 4 days), these might have died thereafter; though certain of them became saints ${ }^{33}$. Only two ${ }^{34}$, however, met, one with the other, like having a date in Paradise, after their death: JC and the Thief.

But of course JC himself was the unique paradigm of resurrection, proving that God can give life to any human already dead, as he did par excellence in the case of his son, being human. This fact is another undisputable proof that God is God of the alive. JC came to earth and died, (in fact assassinated for claiming to be what he was, but this was not understood in Judaea for a number of reasons), and returned alive to his father in heavens (Ascension Day) [4]. If there is a "lad", then the present life with all its malice, unhappiness and unfairness, we believe, can only be tolerated, as provisional, for something better.

\section{Further Basic Concepts of CO-Part II}

Man created completely free ${ }^{35}$; freedom that God respects (!). This freedom entirely confused people, as some they say: "there is no God", or ask: "where is God (?)". And others say: "Man can do anything he/she likes, as God is nowhere"36. He surely is everywhere, and listens even to man's whispers, and knows the thoughts of everyone. He is the super-Mind, and a spirit, but no one except JC knows how God is [4]. If the first couple was not free, how then it is responsible for its disobedience?

True love is free love, we believe, and this cannot be otherwise. Man has to choose among two roads only. God could have implemented a strict control of man, but such a forced love and surveillance would have indeed no value, and

\footnotetext{
${ }^{33} \mathrm{~A}$ number of Saints emerged soon after the time of JC, except the $12+70$ apostles: Veroniki, who suffered from hemorrhage and healed by JC; the 2 sisters of Lazarus of Bethany: Martha and Maria; Maria, the Magdalene, disciple of JC; Proklis, wife of Pilate; St. Fotini, the Samaritan; the Centurion; Judah, son of Joseph from his first wife; to mention only 8. Many became saints also from the disciples of St. Paul, who became Apostles.

${ }^{34}$ JC's mother Maria, Prophet Elias and Patriarch Enoch, as well other saints, "carried" to heavens alive. In the case of the thief, however, his "transfer" has been said and done by JC personally. JC also said that there are some here from those standing that would not "experience" death ([4], p. 285).

${ }^{35}$ Adam thought that to become a God by just eating a piece of fruit, was indeed an extremely challenging, quite easy, and unique opportunity, supported all-heartedly by his wife, who could not think clearly (our words). Adam did not calculate the consequences of his fall as he was indifferent. Eve was assured by D in a private meeting how to become a goddess by telling her lies. JC called D as "the father of lie" ([4], p. 21) and murdered first Man. D planned this carefully and knew that the weaker Eve will be more easily convinced than Adam, and her help would be decisive to convince also him. The bait in this case was: how to acquire "the knowledge of what is right and what is wrong", a property of the "Holy Trinity". God said after Adam's fall: "Behold"! "Adam became now like one of us" [6].

${ }^{36}$ To see JC with human eyes is an exclusive privilege of Saints [4] (e.g. St. Paisios did), but to see his actions, his love, his care, is not difficult to those they observe and recognize his beneficiary acts carefully. Nothing is due to Chance. Moreover, to see God during "lad" one must have a "clean mind".
} 
surely it would not be liked by humans. Man loves freedom. So, God preferred the free human feelings, or even he expects "some sort of sacrifice" (e.g. of a passion) in loving him, as his son did for both us and to him.

St. Paul argued that though man is free to do what he/she likes all his/her actions are not necessarily to his/her interest [4]. This refers mainly ${ }^{37}$ to man's soul, no doubt, but economists bypassed this whole matter conceiving man to have no "spiritual needs". Surely, spiritual wants are not marketed. But do they affect markets, and wealth, and guide man in his/her economic life? We believe yes.

Important is that there is a disguised "antagonism" between "soul" and "body" ([4], pp. 880-881). Which one has a control (Figure 6)? More important is Mind, which has the primary control of all powers of soul and body. Moreover, Mind antagonizes passions, and it is in charge (ruler) of both soul and body.

As shown, the most frequent situation is for body to overrule soul. E.g. sleepiness overruled the soul of the 3 Apostles at "Gethsemane farm", as remarked by JC [4]. Thus most humans will be found to be to the right of the "balanced power" between soul and body, i.e. to the right of the $45^{\circ}$ degrees line. God surely wishes for all to be, as far as one is able by trying, and with God's help, to the left of the $45^{\circ}$ line, where the power of soul over body is unquestionable, overwhelming and permanent ${ }^{38}$.

Worth noting is that something which pleases body may displease soul (and God) [4]. Thus the economics of religion, if ever written, has to establish certain principles: 1) "Utility comes from the satisfaction of 3 types of needs each related to: mind, soul, and body". 2) "Body's utility is of lower value than those of Soul and Mind". 3) Utility released from soul's satisfaction may be felt after death, unlike body, which all its enjoyment is during present I.

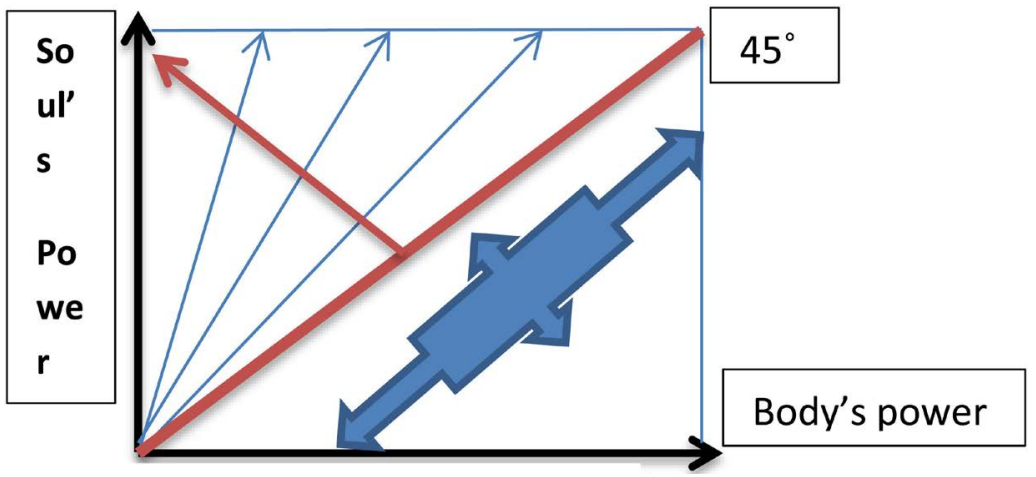

Source: Author.

Figure 6. The sharing of power between soul and body.

${ }^{37} \mathrm{JC}$ showed that sins cause body and soul deceases, and they can "kill" both. One exception is recorded for the power of JC to be shown [4]: e.g. the blind man who could not see, right from his birth, and who did not commit a sin, he or his parents.

${ }^{38}$ For those they want to pursue this issue further they may look at OT [6], Appendix IV, with reference to "Maccabees", mentioned there the power of "godly thoughts derived from mind". In Greek, there is a relevant book written out of certain dialogues carried by Christodoulos Aggeloglou with St. Paisios of Mount Athos (1924-1994) (in 1994), p. 379. 
The existence of soul, and its nature, we reckon, is of prime importance. Is soul immortal? Apropos Man has established a number of sciences dealing with soul $^{39}$. If science examines soul's eternity and if research leads them to a positive answer, then they have to adapt their philosophy accordingly. For CO, soul enters into embryo at the time of conception. This means that an abortion eliminates a prospective body and releases an existing soul. Moreover, Soul is the "chair of one's personality" [4].

Let us now ${ }^{40}$ assume that the eternity of soul is true. Then we have two horizons: 1) the time which body lives, i.e. from one's birth to death and 2) soul's life from 0 to $\infty$ ("lad"). Present life may last, in calendar time, from 0 (conception) ${ }^{41}$ to $\mathrm{n}$ years, if a child is born alive, where $\mathrm{n} \leq 90$, say years, usually $\mathrm{y}^{42}$. Mathematically we have:

$$
\sum_{t=0}^{t=T=90}(B 1 t) /(1+r)^{t}<\sum_{t=0}^{t=T=\infty}(B 2 t) /(1+r)^{t}
$$

where $\mathrm{t}$ stands for time, $\mathrm{T}$ for time horizon, B1t for present life benefits in period $\mathrm{t}$, and B2t benefits during "lad" for $\infty$ time, $\mathrm{r}$ is the social discount rate and $\sum$ is the summation symbol. Inequality (1) means that the present value of the "benefits" one gained from present life (mainly from charity and satisfaction of wants related to body, soul and mind), are far less than the present value of the "benefits" that one will gain during "lad", because $\mathrm{n} \leq 90<\infty$.

Even if we increase the social rate of interest $r$ in the second part of inequality $\{1\}$, due to the uncertainty about "lad" and increase also the \% of risk for the faithless, the above result will not change much. There is also another reason for this result: the costs at present life, though not shown, in order to achieve "lad" benefits are taking place now (mainly charity etc.). These costs would reduce benefits in present life and increase benefits in "lad".

Man is supplied with Mind, Conscience and Personal Merits; also with 2 written "laws"

\footnotetext{
${ }^{39}$ i.e.: psychology, psychiatry, psychophysics, psychoanalysis, psychotherapy, psychosomatic, psychopathology, psychoneurosis, etc.

${ }^{40}$ Keynes ((1936), [5], pp. 140-141) adopted the above discounting technique due to Fisher (1930) [16]).

${ }^{41}$ This formulation stresses also the influence that an embryo receives by the condition of his/her mother (stress, smoking, drugs, fatigue etc.) during pregnancy and from an unfriendly external environment (war, poverty, radiation, family violence, third party smoking etc.).

${ }^{42} \mathrm{An}$ abortion entails usually $\mathrm{n} \leq 84$ only days of life within baby's mother.

${ }^{43}$ The "Old" and especially "New Testament" [4] [6].

${ }^{44}$ Moreover, God fully briefed Adam for the consequences that he would have, if he would disobey his instructions. First, Adam's name given, as this is the custom till this day, by his father (i.e. God), indicating clearly someone coming from soil (="Edem"), and soil surely cannot create a God by itself. Man cannot bring somebody (or something) to existence from zero, as God can do. Physicists "approached" the birth of the universe by "Big Bang". The BB theory argues that the Universe created during an extremely dense and hot situation, 13.8 billion years ago but their assumptions are based on reason. Scientists are unable to conceive that something can be created from nothing. For them must be at least an atom. This theory, however, teaches that god is then the atom! Radford [17] argued that the discovered "gravitational waves" can give the exact moment of the $\mathrm{BB}$, as science was restricted so far to do that by the existing telescopes that could go back only 400,000 years. Physicists thus may find out that at zero time universe was created, but who created it?
} 
sonally by the son of God! Seminars were also delivered from time to time in the past by Prophets to people of Judaea-till the crime of "John the Baptist"; the authority of JC in teaching was, however, unique. The prophesies continued by CO's saints, since then and till this day (e.g. St. Paisios).

JC had used also proofs, i.e. miracles. After JC, his saints continued till this day to deliver seminars to mankind. But worth noting is that fear is not the basis of $\mathrm{CO}$, but the love for God for being so kind; love for other people and love for enemies [4], all being creatures created by the same father, and all have to be rescued from. the two Ds. As God does not want, and has no intention, to "lose" anyone, by respecting one's free will!

Humans we believe have to search, in advance, to find out what is the real meaning and purpose of present life! This, as JC said, is the greatest mistake, which a man can commit [4] by refraining from saving one's soul.

\section{The Human Economics and the Economics of Wealth II}

Human economics started after the "fall" of the first couple of husband and wife, and their forced "landing" outside Paradise, creating there also a family. Before that, they lived in "Paradise economy". Adam and Eve, as we imagine, they had there all goods free, plenty and permanent, though they had to "keep and labor it”. They obtained two sons; Adam then called his wife Zoe (=Life).

Humans seem to lack the knowledge of how to manage the plenty ${ }^{45}$ during their terrestrial life. True that the plenty many times was a factor in economic history, which worked towards the destruction of human nations, and kingdoms, especially richer ones, exactly for the reason that, like Adam and Eve, humans ignored how to deal with abundance for their benefit to gain "lad".

Notable economic exception was Ancient Egypt [5], which in one hand was building pyramids and on the other searched for precious metals they did not stale with abundance. UK enriched an individual enabling him to pile up claims to enjoyment, which he did not intend to exercise at any definite time.

Abundance also made humans to rest, stale, and enjoy present life. Economics talk about scarcity of goods and capital, and stresses the fact that wants are so many that personal incomes are inadequate. It indicates the struggle between the plethora of wants and an ever inadequate income, given inflation.

Adam and Eve were exiled from Paradise where they used to see God and talk to. There is a similar case in NT with the younger son who left his father (God) to test his luck in a foreign country, spending away his whole personal fortune with prostitutes [4]. This is a prior warning of how will be one's life, given that he/she goes away from God and his son and spends an entire property in vain, where a famine has a possibility to occur. This supports Keynes's precautionary motive.

Keynes [5] argued that the marginal propensity to consume is weaker in wealthy communities; and the accumulation of capital is there larger; then the

${ }^{45}$ Wealth (affluence); rich; plentiful; having more than enough. 
opportunities for further investment are less attractive, unless the rate of interest falls at a sufficiently rapid rhythm. He argued that the more virtuous one is, the more decisive in using little food, and the more one insists to be orthodox within national and personal economy, the more incomes must fall ${ }^{46}$ when the rate of interest increases compared with marginal efficiency of capital-MEC.

The real rhythms of total saving and expenditure do not depend on certain 8 merits mentioned by Keynes (like "Pride" and "Avarice" among them), but how much attractive is the rate of interest for investment vis-à-vis MEC [5] (italics added). If gold mined is available, Keynes' experience shows that the real wealth of the world increases rapidly (ibid, p. 130). Economics thus suggests searching for precious metals.

Moreover, millionaires find their satisfaction in building mighty mansions to contain their bodies when alive, and pyramids to shelter them when dead; or, for repenting (them) of their sins, they erect cathedrals and endow monasteries or foreign missions (ibid, p. 220). The trouble arises because the act of saving implies a desire for wealth as such. An increased desire to hold wealth is not the same thing as an increased desire to hold investments or an increased demand for investment.

As a result, Keynes was against personal wealth, which had as a motive to save more today, in order to be able to consume more sometime in the distant future. If to hold wealth depends on a prospective yield, this implies the need of a suitable rate of interest, as we proposed.

Keynes mentioned the case of Midas ${ }^{47}$ for rich communities, as a metaphor when the propensity to consume and the rate of investment are mainly left to the influences of "laissez-faire", instead of deliberately controlled in the social interest [5]. If we can make capital-goods so abundant so that $\mathrm{MEC}=0$, this may be the most sensible way of getting rid of many of the objectionable features of capitalism (ibid, p. 221). Enormous social changes would result from the disappearance of a rate of return on accumulated wealth.

The case-study of the "rich man" in NT, shows that he had also the problem of "how to manage abundance" [4]. He decided to build new warehouses for his new plenty. At the same time "Lazarus" was starving outside his yard. Of course to enjoy goods, or maximize utility, as economists argue, one must live and the duration of one's life is not under one's control. This is why time in the analysis is important to be mentioned.

JC argued that a man may listen to the words of God NT [4], but soon thereafter is drowned away by the torturing effort and care, full of agony, about present life. Moreover, the deceit caused by wealth, sticks one to money, and to easy and convenient enjoyment, and to the vanity of show-off. In another occa-

${ }^{46}$ Income is the result of effective demand: i.e. consumption and investment. If investment and/or consumption fall, then income will fall.

${ }^{47} \mathrm{~A}$ legendary Phrygian king to whom "Dionysus" gave the power of turning everything he touched into gold including his food! This is a metaphor meaning that holding gold does not go along with good health. The mythical god saved him from misery by bidding him bathe in the river called "Pactolus", the sands of which thereafter became gold-bearing (Greek mythology). 
sion JC said to young rich: "go and sell all your property, and give that money to poor and you will have a treasure in heavens; then you are a perfect disciple ${ }^{48}$ of mine" [4]. But he was deeply disappointed, and became very sad, as he was indeed very rich.

Moreover, not only the young rich were surprised by JC's attitude, but also his disciples, asking: "who then really can be saved" (ibid, p. 88)? JC replied that God can correct any mal-relationship between a human and his/her wealth. Then JC said clearly a deep economic proposal: "whoever will abandon houses or brothers or sisters or father or mother or wife or children or property to be united with me forever, he/she will receive 100 times more during his/her present life and in addition he/she will inherit eternal life (ibid, p. 89). The 12 apostles have qualified for this.

JC was clear (ibid, p. 24): "do not gather treasures on earth where, among other probabilities of losses, thieves pierce the walls of the vaults and steal them". "Accumulate treasures in heavens: where there are no thieves" etc. More important was what JC said: "where one's treasure is, there is also his mind stuck" (ibid, p. 24). The accumulation of treasures on earth causes a man to hate God and love the treasures instead. One cannot serve effectively two masters, as the two Masters demand opposite things. One master is God and the other is Wealth (avarice). St. Paul was especially clear by saying that the "root of all evils is avarice" [4]. Avarice makes human blind (ibid, p. 25). Wealth pushes its holder towards an arrogant show-off [6].

JC, however, was especially critical to rich (ibid 262), who used their wealth to comfort and enjoy their body; they get their perfect consolation from wealth and they leave nothing to gain from "lad", he said; pity for those who are full from body enjoyments as a unique end of their life, saying all the time and caring exclusively: "what to eat and drink"? These will be deprived from spiritual goods in "lad", and there they will be hungry. JC remarked that the large properties are made out of injustices [4].

\section{Concluding Remarks}

This paper and its conclusions are based on the fact that $\mathrm{CO}$ is the only true religion and the truths taught by JC are still valid. Economics, and CO, are both against uncontrolled wealth. For Keynes, effective demand, consumption plus investment, helps in achieving full employment. The inducement to save in the form of wealth reduces or postpones expenditure for some unspecified time -something not to the interest of economic growth.

God was the first to foretell Adam about "disutility of labor ${ }^{49}$ ". As a result religion gave economics a very basic principle. Utility, the other face of the same coin, was taken by classical economists to make it a postulate of their employ-

\footnotetext{
${ }^{48} \mathrm{~A}$ prior example is the 12 apostles who left everything and followed JC to "fish" humans.

${ }^{49}$ Keynes [5] argued that the disutility of labor is a reason for a man to withhold his labor, if wage $<$ utility $_{\min }$. And the utility of a wage is = to the marginal disutility of labor. Unemployment is excused if it is frictional (=time lost in job search), seasonal, and voluntary.
} 
ment theory! Economists sought for a balance between two diverse situations on the principle from Physics: "an action causes an equal reaction".

JC meant that whether human, or divine, one has to work. God of course, by asking Adam to work, just after his fall, he wanted him to realize also that he lost the Paradise; there he had only to provide a steady prayer.

Free food can be provided only by God, and his son, in special human circumstances, like the case of "manna". JC, in the eyes of his audience, was the best king of all they had so far, providing "free" meals and "perfect wine", just by a simple prayer to his father, and thus making personal work and disutility of labor redundant! Humans demonstrated to JC that the disutility of labor and the "appreciation of the free possession of food and drink" were placed really high. JC repeatedly tried, however, to redirect their attention, care, agony and pre-occupation from what to "eat, dress and drink" to goods in heavens.

Economics, however, did the opposite: when economists saw that disutility of labor cannot be avoided, "asked" people to maximize their utility. So, the pleasure from consumption compensated disutility from work at the margin mathematically.

Humans were confused by rejecting the principle: "Search and Believe". It is really not conceivable to reject a religion, for which no prior personal research made, and no prior knowledge acquired! It is sure that who knows real God well, it is impossible to reject him. D tries exactly that: he prevents humans from a personal investigation for the existence of God, and for the nature of his love, by saying: "Believe in general but do not search for real God; worship your passions; these are your gods".

Economists failed in their models to take the two "lives"50 of man into account. Also they failed generally by expelling time from their analysis. The duration of one's present "life" and the one in "lad" are both important.

Keynes was successful to describe how human entrepreneurs think by writing: "the thought of ultimate loss, which often overtakes pioneers, as experience undoubtedly tells us, and them, is put aside as a healthy man puts aside the expectation of death [5] (italics added). Do human entrepreneurs believe to be eternal by their absolute confidence on wealth and on their ability to accumulate it?

Robinson J believed that religion is a sentimental system based on faith, while science is a scientific system based on logic, and on experiment. The first, however, uses time from birth to death and after death, and the second uses time during present life only: from birth to death. Who is more right?

The maximization of utility remained as an economic principle after all, providing a deceptive picture of present life. How then can one accept religion, which says that one is going to suffer during present life? A life, during which,

\footnotetext{
${ }^{50}$ Modigliani and Brumberg ([18], introduced the idea of "life-cycle hypothesis" related to "lifetime income", and to "lifetime wealth", but not "lad". They suggested that individuals plan their consumption and savings behavior over their life-cycle. In order to plan they must know the duration of present life. Also the stock of wealth in an economy is related to the length of retirement span: $\mathrm{C}$ $=\mathrm{aW}+\mathrm{bY}\{2\}$. Marginal propensities to consume thus have two sources: wealth $\mathrm{W}$ and income $\mathrm{Y}$. For an updated view see Mankiw [19].
} 
one has to work all along, soon after education, and till one retires? Moreover, work is unpleasant, but one will be compensated for this displeasure by an equal pleasure from eating goods, bought by income as argued by economists. But who is going to compensate one for the misery and miss-happiness of the present life?

Obviously economics, despite other definitions, is the science of how to please one's body. Bentham's attempt, however, of the "beautification" of present life is deceptive, as religion warns that this life is full of mishaps and sorrows mainly due to the improper management of wealth!

Wealth is excluded from frequent economic discussions and even condemned. Wealth brings more wealth, when it reaches a mass quantity (Pareto's power law). Wealth is for the few. Relevant data indicates that rich people get richer as time goes-by, and more so during depressions.

$\mathrm{CO}$ is clear, wealth? Yes, but not here, there (lad). Moreover, and more important, wealth devoted to charity is a passport to eternal life. Create an honest wealth to give it away in charities correcting human inequality. At the same time the poorer by having higher propensity to consume they will boost GDP. With one shot one can kill two birds. This is a point missed by Keynes.

The general and fundamental background question for all religious issues arises, in our humble opinion, as to "what is truth". Our poem in the appendix provides a personal answer as to what truth is. Human happiness, though excluded by God, we all know is not permanent, but either comes and stays for a while, or goes fast away, as a cloud appears and disappears in the sky Disutility of present life.

\section{Conflicts of Interest}

The authors declare no conflicts of interest regarding the publication of this paper.

\section{References}

[1] Blaug, M. (1997) Economic Theory in Retrospect. 5th Edition, Cambridge University Press, Cambridge.

[2] Robinson, J. (1962; 1964) Economic Philosophy. Pelican/Penguin Edition, Bristol, UK.

[3] Gossen, H.H. (1854; 1983) Laws of Human Relations and the Rules of Human Action Derived Therefrom. MIT Press, Cambridge.

[4] Trempelas, P.N. (2016) New Testament (in Greek). 6th Edition, Athens.

[5] Keynes, J.M. (1936; 1961) The General Theory of Employment, Interest and Money. MacMillan \& Co Ltd, London.

[6] Genesis-Scripture/Bible: Old Testament According to the 70s Apostles/The New Testament from Original. Koumoundoureas Editions, Greek.

[7] Weber, M. (1930; 1992; 2001) The Protestant Ethic and the Spirit of Capitalism. T. Parsons, Routledge.

[8] Goulielmos, A.M. (2018) The Nature of Economic Turbulence: The Power De- 
structing Economies with Application to Shipping. Business \& Economics, 9, 1023-1044.

[9] Robinson, J. (1966) The Accumulation of Capital. 2nd Edition, Macmillan, GB.

[10] Varian, R.H. (1990) Intermediate Microeconomics: A Modern Approach. 2nd Edition, W.W. Norton \& Company, New York.

[11] Iyer, S. (2015) The New Economics of Religion, Cambridge-Institute for New Economic Thinking. No 2015/01, Cambridge WP in Economics 1544, Faculty of economics University of Cambridge, Cambridge.

[12] Becker, G. (1964) Human Capital: A Theoretical and Empirical Analysis, with Special Reference to Education. National Bureau of Economic Research, New York.

[13] Teixeira, P.N. (2014) Gary Becker's Early Work on Human Capital-Collaborations and Distinctiveness. Journal of Labor Economics, 3, 12. https://doi.org/10.1186/s40172-014-0012-2

[14] Gurley, J.G. and Shaw, E.S. (1960) Money in a Theory of Finance. Brookings Institution, Washington DC.

[15] Lucas Jr., R.E. (1984) Money in a theory of Finance. Carnegie-Rochester Conference Series on Public Policy, 21, 9-46. https://doi.org/10.1016/0167-2231(84)90003-4

[16] Fisher, I. (1930) The Theory of Interest, as Determined by Impatience to Spend Income and Opportunity to Invest It. Macmillan, New York.

[17] Radford, T. (2016) Gravitational Waves: Discovery Hailed as (the) Breakthrough of the Century, the Guardian.

[18] Modigliani, F. and Brumberg R.H. (1954) Utility Analysis and the Consumption Function: An Interpretation of Cross-Section Data. In: Kurihara, K.K., Eds., Post-Keynesian Economics, Rutgers University Press, Brunswick, NJ, 388-436.

[19] Mankiw, N.G. (2009) Macroeconomics. 7th Edition, Worth, New York. 


\section{Appendix: A Hymn for Truth}

No matter how strange it sounds, Few seek to find Truth in the surrounds!

The majority seeks Happiness, but they get pity, As permanent Happiness does not exist in any City.

Truth has a sister called Freedom, but Truth's family is a small Kingdom, it has three other sisters apart from Justice:

Love, Faith and Hope.

Truth is the love for the real, hope for future, with no fear, and faith in the darkness.

Truth throws light in our night, and provides the sun in our life.

Truth is not just a concept, Or a little philosophy,

It is a Person, and a supreme wisdom,

It cannot be approached by reason,

Frequently however visits faith's "prison".

Truth does not change, remains the same; Technology cannot alter its nature or its fame. Everywhere truth emerges as spirit, personally, And who has found it keeps it un-provisionally.

Many of those seeking the truth,

They look for it in the wrong place,

As Truth is everywhere, but "elsewhere" is her face.

And there are times that Truth finds you,

But to find Truth early is better for you.

"What is Truth?" many have asked,

Even Pontius Pilate ${ }^{51}$, but they got no reply,

Because this question was wrong, as is not "what", but "who"...

Truth is revealed to those that can love-it-by, And to those asking by curiosity remains hidden, As easily it is not surrendered to anyone nearby.

${ }^{51} \mathrm{He}$ was a Roman Governor of Judaea, during A.D. 26-36, and presided at JC's trial. 
Who finds Truth, happiness for him is nil,

As one feels free, and death is not felt,

$\mathrm{He} / \mathrm{she}$ hopes in life after death,

When truth is really and finally met,

but this is too late! 